\title{
Proteomic Analysis of Diversified Extremophilic Strains of Pseudomonas in the Presence of Cadmium
}

\author{
Sourabh Jain · Arun Bhatt
}

Received: 9 May 2013/Accepted: 20 September 2013/Published online: 15 October 2013

(C) NAAS (National Academy of Agricultural Sciences) 2013

\begin{abstract}
Environmental contamination caused by heavy metals, such as cadmium $(\mathrm{Cd})$, is a serious and growing concern. $\mathrm{Cd}$ is a highly toxic and carcinogenic metal for humans, animals and plants and is a widespread pollutant with a long biological life. The presence and persistence of growth promoting metal-resistant microbial community in the soil system facilitates remediation of $\mathrm{Cd}$. This study deals with proteomic characterization of cadmium-resistant diversified isolates of Pseudomonas spp., i.e., psychrotolerant P. putida (isolate SB32) and alkalophilic P. monteilli (isolate SB35). Further, two-dimensional gel electrophoresis (2DE) revealed 24 proteins in SB32 and 21 proteins in SB35, differentially expressed after Cd exposure. On the basis of their increased expression, two protein spots in SB32 and one in SB35 were selected for further analysis. With MS/MS spectra produced by LC-MS analysis, spots were identified through NCBI EST database searching with Mascot MS/MS Ion Search Engines (Matrix Sciences). Spots from cadmium-treated P. putida SB32 appear to be ATP-dependent Clp protease subunit and 20S proteasome, A and B subunits, while spot from cadmiumtreated P. monteilli SB35 appears to be nitroreductase. Protein identification supports that interplay between protein folding and hydrolysis may be a central mechanism for proper cell function survival in the presence of cadmium.
\end{abstract}

Keywords Cadmium $\cdot$ Pseudomonas $\cdot$ Proteomics $\cdot$ Psychrotolerant $\cdot$ Alkalophilic

\section{Introduction}

Contamination of soil and groundwater with heavy metals poses a major environmental and human health problem because they are very toxic and have intrinsically persistent nature. In particular, cadmium is very toxic and probably carcinogenic at low concentrations. Cadmium is released into the environment through various industrial discharges of metal plating, Ni-Cd batteries, pigments and plastics, cigarette smoking, smelting operations, incineration of

\footnotetext{
A. Bhatt $(\bowtie)$

Department of Crop Improvement, Uttarakhand University of Horticulture and Forestry, Uttarakhand, India

e-mail: bhatt.gbpec@gmail.com; arun.bhatt@rediffmail.com

S. Jain

National Research Centre on Plant Biotechnology, IARI

Campus, Pusa, New Delhi, India
}

municipal waste, sewage sludge, chemical fertilizers and polluted groundwater $[22,29] . \mathrm{Cd}^{2+}$, a designated human carcinogen, is one of well-known toxic heavy metal ions, and its toxicity has been extensively studied [1, 8, 28, 32, 37]. It has been proposed that $\mathrm{Cd}^{2+}$ ions might displace $\mathrm{Zn}^{2+}$ and $\mathrm{Fe}^{2+}$ in proteins [34], resulting in their inactivation and in the release of free iron, which might generate highly reactive hydroxyl radicals $\left(\mathrm{OH}^{\prime}\right)$ [11]. In support of this hypothesis, a major effect of cadmium is oxidative stress [2], particularly lipid peroxidation [33].

Cadmium has no biological function, but hampers the normal functions of life when it accumulates within the living system above the toxicity level. All prokaryotes and eukaryotes have developed mechanisms to prevent excessive accumulation of $\mathrm{Cd}$ in the cells. The relatively low intracellular $\mathrm{Cd}$ concentration is maintained through the regulation of sequestration or efflux. Microorganisms are well reported to both biotransform [14] and adsorb $\mathrm{Cd}$ on 
their cell surface (Watcharamusika et al. 2008). Microbial resistance to $\mathrm{Cd}$ is usually based on energy-dependent efflux mechanisms [25, 30]. Pseudomonas putida is a ubiquitous saprophytic bacterial species that is known not only for the ability to degrade various biogenic and xenobiotic pollutants [35] but also for the tolerance to heavy metal ions $[15,21,26,36]$. They have been extensively studied for their well-adapted metal resistance properties [31].

The analysis of plant protein profiles under different treatments is a powerful approach to identify stressresponsive proteins and to elucidate the crucial pathways involved in stress resistance [39]. The combination of twodimensional differential gel electrophoresis (2D-DIGE) and MALDI-TOF MS/MS analysis allows rapid and accurate separation and identification of hundreds of proteins. The DNA genomic sequence has been considered by some as a basic framework for further investigations into mechanisms of gene action [38]. Because the amount of protein is often not predictable from the amount of mRNA produced in the cell, and post-translational modifications such as phosphorylation and glycosylation can be vital for cellular functions, the study of proteins is crucial to judiciously examine their levels and activities at a given time in a cell, or in response to various environmental conditions [40]. It is inevitable that the study of the cellular responses to different stresses at the proteomic level will inform us what gene products are actually expressed and their changes.

The overall goal of this study was to identify proteins that were expressed in the presence of cadmium by comparing protein expression patterns of diversified extremophilic strains of Pseudomonas spp. in the presence and absence of cadmium, respectively.

\section{Materials and Methods}

Strains and Culture Conditions

Psychrotolerant strain SB32 and alkalophilic strain SB35 ( $\mathrm{pH}$ 9.0), originally isolated from soil samples from Semera mines, Palamau, Jharkhand, were obtained from departmental culture collection. Both the strains were maintained on nutrient agar medium supplemented with $1 \mathrm{mM} \mathrm{CdCl}{ }_{2}$ concentration with their respective $\mathrm{pH}$ and temperature conditions. The plates were incubated at $30{ }^{\circ} \mathrm{C}$.

\section{Protein Extraction}

Proteins were extracted from SB32 and SB35 strains. Single colony of bacterial culture was inoculated in $500 \mathrm{ml}$ of broth and grown overnight in the presence and/or absence of cadmium, respectively. Culture was harvested at 10,000 rpm for $10 \mathrm{~min}$, and pellet was washed twice with normal saline solution. Pellet was then dissolved in $4 \mathrm{ml}$ of $0.1 \mathrm{M}$ phosphate buffer saline (chilled) and sonicated for $3 \mathrm{~min}$ in ice. One mM PMSF $(100 \mu \mathrm{L})$ was added to the sonicated pellet. Cell suspension was centrifuged for $45 \mathrm{~min}$ at $10,000 \mathrm{rpm}$.

\section{Two-Dimensional (2D) Gel Electrophoresis}

For first dimension electrophoresis (isoelectric focusing, IEF), a 17-cm-long immobilized $\mathrm{pH}$ gradient, 3-10 Ready Strip IPG strips (Bio-Rad, Hercules, CA, USA) were passively rehydrated for $18 \mathrm{~h}$ at $50 \mathrm{~V}$ and $20^{\circ} \mathrm{C}$ with $100 \mu \mathrm{g}$ of protein extract suspended in IEF buffer. IEF was done using a Protean IEF cell (Bio-Rad) at a current limit of $50 \mu \mathrm{A} /$ strip at $20{ }^{\circ} \mathrm{C}$ with the following steps: active rehydration at $250 \mathrm{~V}$ for $12 \mathrm{~h} ; 250 \mathrm{~V}$ (linear) for $15 \mathrm{~min}$; $10 \mathrm{kV}$ (linear) for $3 \mathrm{~h}$; and $10 \mathrm{kV}$ (rapid) until a total $80 \mathrm{kVh}$ for a combined total of approximately $92 \mathrm{kVh}$. After IEF separation, each focused IPG strip was equilibrated by soaking, with mild stirring, in $6 \mathrm{ml}$ of equilibration base buffer [ $8 \mathrm{M}$ urea, $2 \%(\mathrm{w} / \mathrm{v})$ sodium dodecyl sulfate (SDS), $50 \mathrm{mM}$ Tris- $\mathrm{HCl}(\mathrm{pH} 8.8), 20 \%(\mathrm{v} / \mathrm{v})$ glycerol, $1 \%(\mathrm{w} / \mathrm{v}) \mathrm{DTT}]$ for $20 \mathrm{~min}$. Second dimension electrophoresis (SDS-PAGE) was performed in $12.0 \%$ gradient SDS-polyacrylamide gel. For molecular weight determination, precision protein standard markers (BioRad, Hercules, CA, USA) were used. Proteins were visualized by gel staining with silver nitrate. All 2D experiments were carried out in triplicate.

\section{Proteomic Profiling and Difference in Gel Electrophoresis}

Preparative 2D gels of samples intended for mass spectrometry and loaded with $1.0 \mathrm{mg}$ protein were stained overnight with Bio-Safe Coomassie Brilliant Blue R250 (0.1\% solution) (Bio-Rad Laboratories, Hercules, CA) and destained with water. Spots of interest were excised from the gel; the gel pieces were washed with water and destained with $50 \mathrm{mM} \quad \mathrm{NH}_{4} \mathrm{HCO}_{3} / 50 \%$ acetonitrile $(\mathrm{ACN})$. Proteins were reduced by incubation with $10 \mathrm{mM}$ dithiothreitol in $100 \mathrm{mM} \mathrm{NH} \mathrm{NCO}_{3}$ at $50{ }^{\circ} \mathrm{C}$ for $30 \mathrm{~min}$ and then alkylated by incubation with $55 \mathrm{mM}$ iodoacetamide in $100 \mathrm{mM} \mathrm{NH}_{4} \mathrm{HCO}_{3}$ for $30 \mathrm{~min}$ in the dark. After being dehydrated with $100 \% \mathrm{ACN}$ and air-dried, the gel pieces were rehydrated for $10 \mathrm{~min}$ in a trypsin solution (Promega Corporation, Madison, Wisconsin) in a ratio of approximately $1: 10(\mathrm{w} / \mathrm{w})$ of trypsin/protein. Fifty microliters of $50 \mathrm{mM} \mathrm{NH}_{4} \mathrm{HCO}_{3}(\mathrm{pH} \mathrm{8.0)}$ was added to each gel piece, and the proteins were digested at $37{ }^{\circ} \mathrm{C}$ for $18 \mathrm{~h}$. The 
peptides were extracted by vortexing and then concentrated to $10 \mu \mathrm{L}$ in a Speed-Vac. The samples were cleaned using a C-18 ZipTip system (Millipore) and eluted with $5 \mu \mathrm{L}$ of $50 \% \mathrm{ACN}$. One microliter of $1 \%$ formic acid was added to the eluate to protonate peptides. Mass spectrometry was performed using nano-spray injection as the sample delivery method. The $6 \mu \mathrm{L}$ of the sample was injected into nano-LCMS (Thermofinnnigan LCQ Deca). The parental and fragment mass error were 0.2 and 0.1 Da, respectively, and trypsin was set as the digestion enzyme with one missed cleavage allowed. Carbamidomethylation and methionine oxidation were set as the fixed and variable post-translational modifications, respectively.

MS/MS spectra were used to search against the NCBI non-redundant protein database using MS/MS Ion Search Engine, a computer software program conducting protein identification based on matching the MS/MS spectra of a protein with a protein or DNA sequence database (http://www.matrixscience.com/search_form_select.html). The searches were restricted to the bacterial taxonomy. The significance of the protein match with the ion score was based on the Mouse scoring algorithm. The ion score was calculated as $-10 \times \operatorname{LOG}_{10}(P)$, where $P$ is the absolute probability that the observed match is a random event. Thus, a relatively small $P$ value means that the match of identified protein and the MS/MS spectra is not a random event. A significant specific match increases the ion score, so a high score means highly significant matching (MASCOT Help; http://www.matrixscience.com/help/scoring_ help.html\#PBM). A single protein having a higher score than the minimum score for the significance level $(p<0.05)$ was judged as a significant match. In each MASCOT search output result, the minimum score for significance level was provided, based on the absolute probability and the size of the sequence database being searched. Identified proteins were aligned to sequences in the Swiss-Prot database using the NCBI BLAST (blastp) tool to confirm the assigned proteins.

\section{Results and Discussion}

Identification of the cadmium-induced proteins in P. putida SB32 and P. monteilli SB35

Investigation into the global stress response generated by cadmium on the bacterial strains identified potentially important proteins that involved in cadmium detoxification and metabolism. The protein extract prepared from the cells in the mid-exponential phase were analyzed by $2 \mathrm{D}$ gel electrophoresis and visualized by $\mathrm{CBB}$ staining. Figures 1 and 2 show the profile of the two-dimensional gel electrophoresis of the extract prepared from non-treated cells (1a, 2a) and cadmium-treated cells $(1 \mathrm{~b}, 2 \mathrm{~b})$ of $P$. putida SB32 and $P$. monteilli SB35, respectively. Interestingly, some proteins were highly expressed in the cadmiumtreated cells. In order to characterize these cadmiuminduced proteins, the overexpressed spots (nos. 15, 24 from $P$. putida SB32 and 5 from $P$. monteilli SB35) in the absence and presence of cadmium were excised from the gel and identified (Fig. 3a-f).

Spot no. 15 appears to be ATP-dependent Clp protease subunit. Energy-dependent proteases have been identified in all organisms analyzed and, although not universally distributed, include the Lon, FtsH (HflB), ClpAP, ClpXP, HslUV (ClpYQ) and proteasome complexes [6, 23].Several of these proteases are stress or heat shock inducible including ClpXP [10, 18], Lon [9, 12, 27], FtsH [12, 13], HslUV [4], and subunits of the proteasome (17). The Clp protease system was first identified in Escherichia coli and consists of two non-homologous components: a proteolytic subunit known as ClpP and an ATPase subunit (ClpA). The ATPase subunit is required for binding and unfolding of the protein substrates and then transferring it to the ClpP protease for degradation [28]. Two distinct ATPase subunits in E. coli, ClpA (83 kDa) and ClpX (46 kDa), are known to associate transiently with ClpP (21.5 kDa). Due to their difference in substrate specificity, the subsequent proteases degrade different types of proteins [16].

The up-regulation of ATP-dependent C1 protease subunit reveals that this protein is an induced stress protein that may be involved in bacterial acclimation to cadmium. Penaud et al. [27] reported the induction of ATP-dependent $\mathrm{C} 1$ protease proteolytic subunit during acid adaptation in Lactobacillus bulgaricus.

Spot no. 24 appears to be proteasome, A and B subunits. The 20S proteasome, the proteolytic core in the 26 proteasome, is known to be involved in the degradation of proteins modified by oxidation. The $20 \mathrm{~S}$ proteasome homologues were discovered within the genome of Actinomycetes [24], a lineage of high-GC Gram-positive bacteria, including Streptomyces coelicolor A3(2) [6, 24], Mycobacterium leprae and Mycobacterium smegmatis [17], Mycobacterium tuberculosis [5] and Rhodococcus erythropolis [41]. No known function could be attributed to the $20 \mathrm{~S}$ proteasome in bacteria so far, except for the $M$. tuberculosis proteasome that has been found to protect the organism against oxidative or nitrosative stress [5].

Amino acids of proteins can be modified by the oxygen radicals or other activated oxygen produced as by-products of cellular metabolism or from the response to abiotic or biotic stress. Subsequently, oxidative modified proteins can undergo chemical fragmentation or form aggregates due to covalent cross-linking reactions and increased surface hydrophobic. Abnormal proteins that accumulate after exposure to stresses such as heavy metals stress, heat shock 

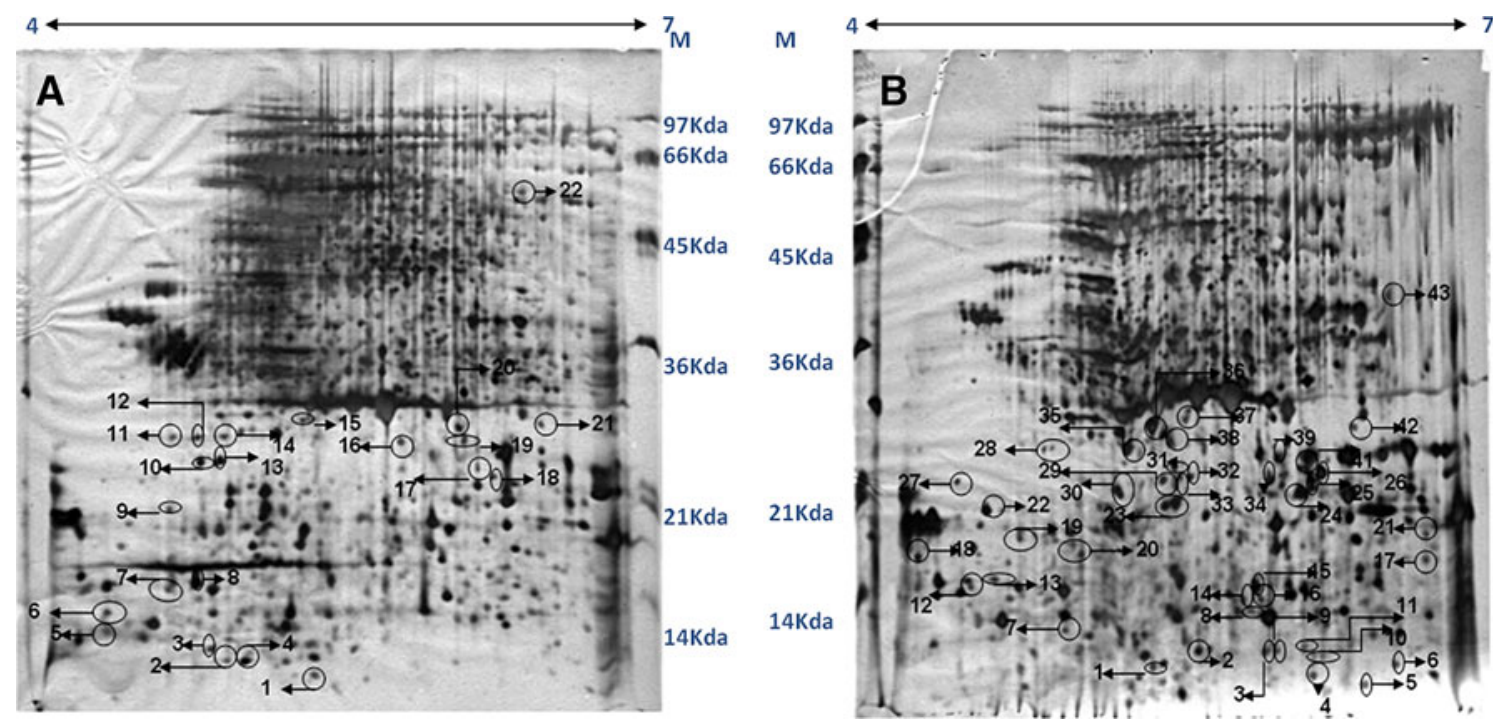

Fig. 1 Two-dimensional gel depicting total bacterial ( $P$. putida SB32) protein expressed in the absence (a) and presence of cadmium (b), wherein $\mathrm{pH}$ range was $4-7$, and $M$ represent molecular weight markers in $\mathrm{kDa}$
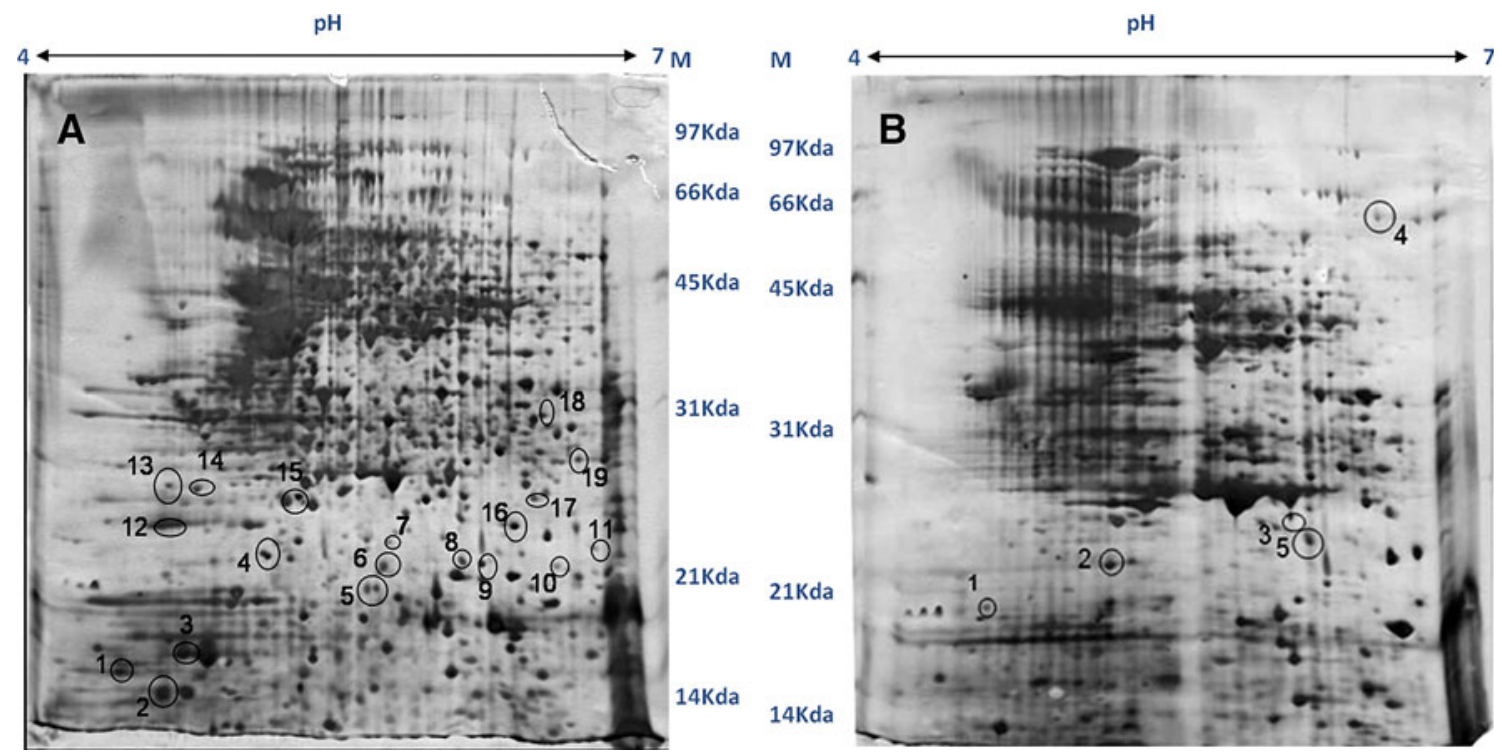

Fig. 2 Two-dimensional gel depicting total bacterial ( $P$. monteilli SB35) protein expressed in the absence (a) and presence of cadmium (b), respectively, wherein $\mathrm{pH}$ range was $4-7$, and $M$ represent molecular weight markers in $\mathrm{kDa}$

or oxidative damage are specifically targeted for hydrolysis. The up-regulation of $20 \mathrm{~S}$ proteasome in this study may be involved in the defence against oxidative stress, which is consistent with the up-regulation of several antioxidant proteins in cadmium stress. The effects of cadmium $(\mathrm{Cd})$ on cellular proteolytic responses were investigated in the roots and leaves of tomato (Solanum lycopersicum L., var Ibiza) plants. The up-regulation of the $20 \mathrm{~S}$ proteasome gene expression and proteolytic activity argues in favor of the involvement of the $20 \mathrm{~S}$ proteasome in the degradation of oxidized proteins in plants [7].
Spot no. 5 appears to be nitroreductase. Nitroreductase reduces nitro groups on explosives and other nitroaromatic compounds and removes nitrogen from rings structure. The nitroreductase can utilize either NADH or NADPH as a source of reducing equivalents and can reduce a variety of nitroaromatic compounds including nitrofurans and nitrobenzenes as well as quinones. Nitroreductase have been reported in Clostridium acetobutylicum ATCC 824 [19], E. coli, Enterobacter cloacae [3] and in some plants [34]. In a study performed by Kwak et al., [20], chromatereducing activities of E. coli DH5 and Vibrio harveyi 

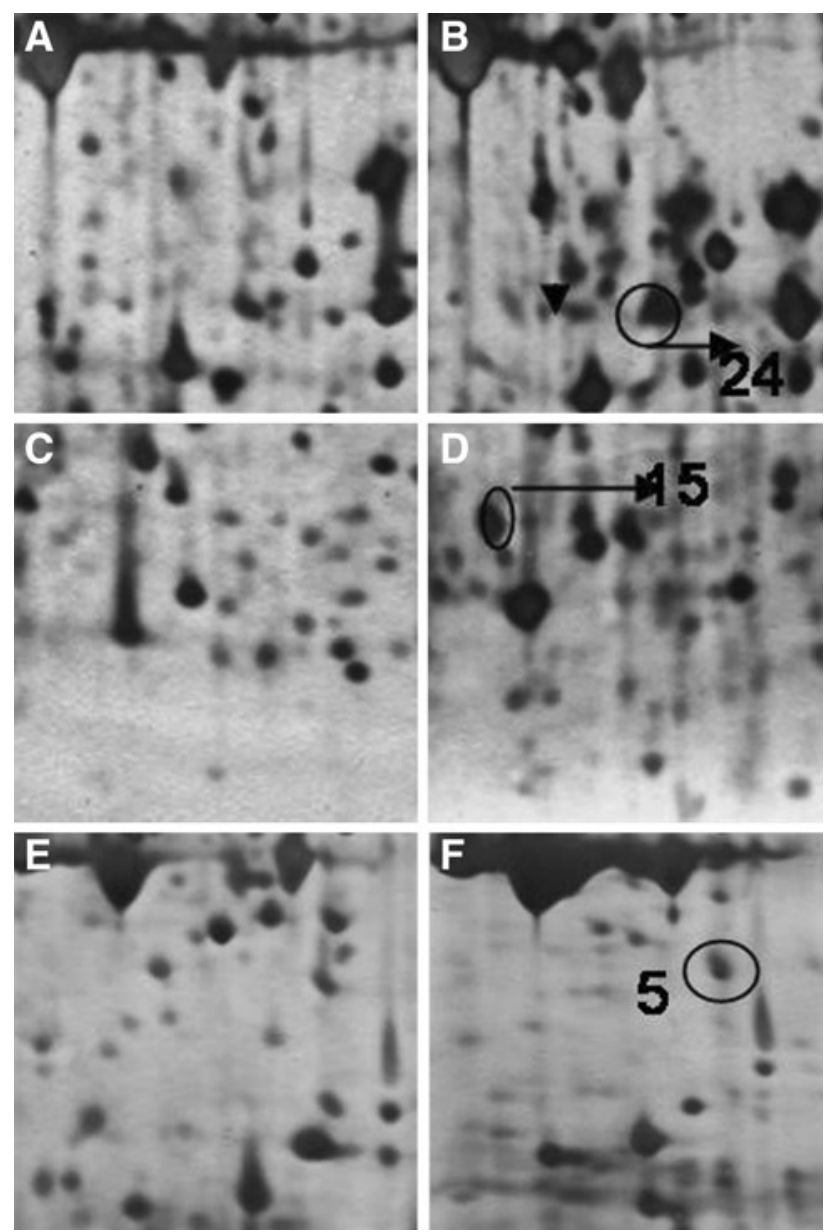

Fig. 3 Depiction of relative abundance of the protein spot (circled) in the presence of cadmium, wherein a untreated $P$. putida SB32, b Cdtreated $P$. putida SB32, c untreated $P$. putida SB32, d Cd-treated $P$. putida SB32, e untreated $P$. monteilli SB35, f Cd-treated $P$. monteilli SB35

KCTC 2720 nitroreductases were determined. Similarly, the chromate reductase purified from Pseudomonas ambigua was found to be homologous with several nitroreductases [20].

\section{Conclusion}

Heavy metal-resistant bacteria containing different detoxification mechanisms have been previously shown to alleviate the inhibitory effects of various heavy metals on plant growth. However, how the bacteria react to the heavy metals stresses has not been previously characterized. In this work, an examination of the proteome of both the isolates $P$. putida SB32 and $P$. monteilli SB35 revealed systematic cadmium resistance responses of these bacteria including general stress adaptation and anti-oxidative stress, which may be useful in the development of bioremediation protocols.
Based on the elevated production of ATP-dependent Clp protease and $20 \mathrm{~S}$ proteasome, A and B subunits, it appears that cells growing in the presence of cadmium have an increased demand for the recognition and elimination of abnormal proteins accumulate after exposure to oxidative damage. Nitroreductase reduces nitro groups on explosives and nitroaromatic compounds and removes nitrogen from ring structures, but the role of nitroreductase in the presence of heavy metal has not been deciphered till now. To the best of our knowledge, the occurrence of ATP-dependent Clp protease, 20S proteasome, A and B subunits, and nitroreductase has never been reported in bacteria in the presence of cadmium so far and might constitute a link between these proteins and cadmium resistance.

Acknowledgments This study was supported by Junior Research Fellowship to S.J. by DBT-India. Authors also acknowledge Genetix Biotech Asia Pvt. Ltd., for 2D gels.

Conflict of interest None.

\section{References}

1. Beyersmann D, Hechtenberg S (1997) Cadmium, gene regulation, and cellular signalling in mammalian cells. Toxicol Appl Pharmacol 144:247-261

2. Brennan RJ, Schiestl RH (1996) Cadmium is an inducer of oxidative stress in yeast. Mutat Res 356:171-178

3. Bryant C, DeYuka M (1991) Purification and characterization of an oxygen-insensitive NAD(P)H nitroreductase from Enterobacter cloacae. Biol Chem 266(7):4119-4129

4. Chuang SE, Burland V, Plunkett G, Daniels DL, Blattner FR (1993) Sequence analysis of four new heat-shock genes constituting the $h s l T S / i b p A B$ and hslVU operons in Escherichia coli. Gene 134:1-6

5. Darwin KH, Ehrt S, Gutierrez-Ramos JC, Weich N, Nathan CF (2003) The proteasome of Mycobacterium tuberculosis is required for resistance to nitric oxide. Science 302:1963-1966

6. De Mot R, Nagy I, Walz J, Baumeister W (1999) Proteasomes and other self-compartmentalizing proteases in prokaryotes. Trends Microbiol 7:88-92

7. Djebali W, Gallusci P, Polge C, Boulila L, Galtier N, Raymond P, Chaibi W, Brouquisse R (2008) Modifications in endopeptidase and $20 \mathrm{~S}$ proteasome expression and activities in cadmium treated tomato (Solanum lycopersicum L.) plants. Planta 227(3):625-639

8. Goering P, Waalkes M, Klaassen C (1994) Toxicology of cadmium. In: Goyer RA, Cherian M (eds) Handbook of experimental pharmacology, vol 115. Springer, New York, pp 189-214

9. Goff SA, Casson LP, Goldberg AL (1984) Heat shock regulatory gene htpR influences rates of protein degradation and expression of the lon gene in Escherichia coli. Proc Natl Acad Sci USA 81:6647-6651

10. Gottesman S, Clark WP, De Crecy-Lagard V, Maurizi MR (1993) $\mathrm{ClpX}$, an alternative subunit for the ATP-dependent Clp protease of Escherichia coli. Sequence and in vivo activities. J Biol Chem 268:22618-22626

11. Halliwell B, Gutteridge JMC (1984) Oxygen toxicity, oxygen radicals, transition metals and disease. Biochem J 219:1-14

12. Hecker M, Schumann W, Volker U (1996) Heat-shock and general stress response in Bacillus subtilis. Mol Microbiol 19:417-428 
13. Herman C, Thevenet D, D'Ari R, Bouloc P (1995) Degradation of sigma 32, the heat shock regulator in Escherichia coli, is governed by HflB. Proc Natl Acad Sci USA 92:3516-3520

14. Higham DP, Sadler PJ, Scawen MD (1985) Cadmium resistance in Pseudomonas putida: growth and uptake of cadmium. J Gen Microbiol 131:2539-2544

15. Horitsu H, Yamamoto K, Wachi S, Kawai K, Fukuchi A (1986) Plasmid-determined cadmium resistance in Pseudomonas putida GAM-1 isolated from soil. J Bacteriol 165:334-335

16. Hwang BJ, Park WJ, Chung CH, Goldberg AL (1987) Escherichia coli contains a soluble ATP-dependent protease (Ti) distinct from protease La. Proc Natl Acad Sci USA 84(16): $5550-5554$

17. Knipfer N, Shrader TE (1997) Inactivation of the 20S proteasome in Mycobacterium smegmatis. Mol Microbiol 25:375-383

18. Kroh HE, Simon LD (1990) The ClpP component of Clp protease is the sigma 32-dependent heat shock protein F21.5. J Bacteriol 172:6026-6034

19. Kutty R, Bennet GN (2005) Biochemical characterization of trinitrotoluene transforming oxygen-insensitive nitroreductases from Clostridium acetobutylicum ATCC 824. Arch Microbiol 184(3):158-167

20. Kwak YH, Lee DS, Kim HB (2003) Vibrio harveyi nitroreductase is also a chromate reductase. Appl Environ Microbiol 68(8): 4390-4395

21. Lee SW, Glickmann E, Cooksey DA (2001) Chromosomal locus for cadmium resistance in Pseudomonas putida consisting of a cadmium-transporting ATPase and a MerR family response regulator. Appl Environ Microbiol 67:1437-1444

22. Lu LT, Chang IC, Hsiao TY, Yu YH, Ma HW (2007) Identification of pollution source of cadmium in soil: application of material flow analysis and a case study in Taiwan. Environ Sci Pollut Res Int 14:49-59

23. Lupas A, Flanagan JM, Tamura T, Baumeister W (1997) Selfcompartmentalizing proteases. Trends Biochem Sci 22:399-404

24. Nagy I, Tamura T, Vanderleyden J, Baumeister W, De Mot R (1998) The 20S proteasome of Streptomyces coelicolor. J Bacteriol 180:5448-5453

25. Nies DH (2003) Efflux-mediated heavy metal resistance in prokaryotes. FEMS Microbiol 27:313-339

26. Pardo R, Herguedas M, Barrado E, Vega M (2003) Biosorption of cadmium, copper, lead and zinc by inactive biomass of Pseudomonas Putida. Anal Bioanal Chem 376:26-32
27. Phillips TA, VanBogelen RA, Neidhardt FC (1984) lon gene product of Escherichia coli is a heat-shock protein. J Bacteriol 159:283-287

28. Prozialeck WC (2000) Evidence that E-cadherin may be a target for cadmium toxicity in epithelial cells. Toxicol Appl Pharmacol 164:231-249

29. Ramos L, Fernández MA, González MJ, Hernández LM (1999) Heavy metal pollution in water, sediments, and earthworms from the Ebro River, Spain. Bull Environ Contam Toxicol 63:305-311

30. Silver S (1996) Bacterial resistances to toxic metal ions: a review. Gene 179:9-19

31. Singh V, Chauhan PK, Kanta R, Dhewa T, Kumar V (2010) Isolation and characterization of Pseudomonas resistant to heavy metal contaminants. Int J Pharm Sci Rev Res 3:164-167

32. Stafford SJ, Humphreys DP, Lund PA (1999) Mutations in dsbA and $\mathrm{dsbB}$, but not dsbC, lead to an enhanced sensitivity of Escherichia coli to $\mathrm{Hg} 2+$ and $\mathrm{Cd} 2+$. FEMS Microbiol Lett 174:179-184

33. Stohs SJ, Bagchi D (1995) Oxidative mechanisms in the toxicity of metal ions. Free Radic Biol Med 18:321-336

34. Susarla S, Medina VF, McCutcheon SC (2002) Phytoremediation: an ecological solution to organic chemical contamination. Ecol Eng 18:647-658

35. Timmis KN (2002) Pseudomonas putida: a cosmopolitan opportunist par excellence. Environ Microbiol 4:779-781

36. Tripathi M, Munot HP, Shouche Y, Meyer JM, Goel R (2005) Isolation and functional characterization of siderophore-producing lead- and cadmium-resistant Pseudomonas putida KNP9. Curr Microbiol 50(5):233-237

37. Vallee BL, Ulmer DD (1972) Biochemical effects of mercury, cadmium, and lead. Annu Rev Biochem 41:91-128

38. Whitelegge PJ (2002) Plant proteomics: BLASTing out of a MudPIT. PNAS 99:11564-11566

39. Xu C, Huang B (2010) Differential proteomic response to heat stress in thermal Agrostis scabra and heat-sensitive Agrostis stolonifera. Physiol Plant 139:192-204

40. Zivy M, de Vienne D (2000) Proteomics: a link between genomics, genetics and physiology. Plant Mol Biol 44:575-580

41. Zuhl F, Seemuller E, Golbik R, Baumeister W (1997) Dissecting the assembly pathway of the $20 \mathrm{~S}$ proteasome. FEBS Lett 418:189-194 